\author{
Kamila Rezmer-Płotka \\ Nicolaus Copernicus University, Poland \\ ORCID: https://orcid.org/0000-0002-1458-5076 \\ e-mail: kamila.rezmer@onet.pl
}

\title{
Possibility of Implementing the Concept of the Intermarium in the Context of Militant Democracy in Poland During and After the Coronavirus Pandemic ${ }^{1}$
}

\begin{abstract}
Intermarium is one of the most important Polish geopolitical concepts. This article considers it within the category of militant democracy. It allows to explore the process of militant democracy, that is, introducing restrictions by legal means. Most restrictions have recently been introduced due to a coronavirus pandemic. Therefore, the article undertakes to examine the potential for implementation of the concept of the Intermarium during the pandemic and shortly after its end. The study uses a qualitative analysis of sources. Indicators relevant to the study of the process of militant democracy were distinguished based on the body of literature. Results: The traditional concept of the Intermarium erodes due to natural causes. Currently, Poland is more inclined to the concept of the Three Seas. In addition, in the face of the analysis that was carried out, it seems that in a pandemic situation we are observing the end of the paradigm of liberal democracy in this case.
\end{abstract}

Keywords: militant democracy, coronavirus, COVID-19, Poland, Intermarium, pandemic, Three Seas

\section{Introduction}

Intermarium is considered as one of the most important Polish geopolitical concepts (Sykulski, 2014, p. 118). The concept regularly returns to political discourse from its inception to the present day. It now appears to deserve special attention during the coronavirus pandemic (COVID-19) that has taken place. In the face of such a large-scale phenomenon, many con-

1 This paper is a result of the research project Contentious Politics and Neo-Militant Democracy. It was financially supported by the National Science Centre, Poland [grant number 2018/31/B/HS5/01410]. 
cepts may be redefined or will require at least second thoughts. A useful category that allows to think in an original way about the concept of the Intermarium, used in this article, is militant democracy. Its origins should be sought in the works of Karl Loewenstein, who used it to analyze the Weimar Republic, seeking premises for its failure in the fight against Nazism (Loewenstein, 1937a, pp.417-432; Loewestein, 1937b, pp.638-658). In this article, militant democracy is understood as a political regime in which both parliament (Marszałek-Kawa, 2019) and the judiciary have legal means to limit individual democratic freedoms in order to defend democracy against those who are considered its enemies (Loewenstein, 1937a, p. 418; Molier \& Rijpkema, 2017, pp. 394-409). Significance features of militant democracy distinguished on the basis of the literature on the subject seem to be revealed especially during the COVID-19 pandemic. For this reason, it is interesting to look at the concept of the Intermarium in its context, in order to wonder does in the current situation this idea has a chance of implementation or further existence, especially in the period right after the end of the pandemic, when the whole world will struggle with its effects. The study uses a qualitative analysis of sources, and through their targeted selection it became possible to collect the most important data related to the process of becoming militant democracy. The indicators that have been highlighted based on the literature review are: the limitations of the freedom of assembly (M1) (Mareš, 2005, p. 34), the limitations of the freedom of the press (M2) (Capoccia, 2005, pp. 57-61), the limitations of the freedom of speech (M3) (Ijabs, 2016, p. 289; Mareš, 2012, p. 36), the limitations of the freedom of association (M4) (Mareš, 2012, p. 36), the limitations of the freedom of religion (M5) (Müller, 2012, p. 1119), the limitations of passive voting rights (M6) (Ijabs, 2016, p. 289), the limitations of active voting rights (M7) (Ijabs, 2016, p. 289), the limitations of referendum organization (W8) (Ijabs, 2016, p. 288), legislation on counterterrorism and anti-terrorism (M9) (Macklem, 2006, pp. 488-489), the limitation of registration and functioning of political parties (M10) (Mareš, 2012, p. 36), the limitation of naturalization (M11) (Ijabs, 2016, p. 289), the limitation of access to public employment (M12) (Mareš, 2012, p. 36), legislation on anti-extremism (M13) (Capoccia, 2005, pp. 57-61; Sajó, 2005, p. 2280), movement restrictions (M14) (Sajó, 2005, p. 2280), restrictions on the independence of the judiciary (M15) (Kirshner, 2014,p. 21). As part of the study, it seems reasonable to ask the following research question: what is the potential for implementing the concept of the Intermarium in the context of the process of becoming a militant democracy during the COVID-19 pandemic? Currently, one can come across the concept of the Intermarium, referred to as the „three sea” assuming the US support for Poland (Jakóbik, 2017), which should be mentioned, although the used nomenclature raises doubts (Zaniewicz, 2017). In the case of this article, however, attention is focused on the concept of the Intermarium in relations with Poland and Russia, which is closer to its original version. As such, it can be treated as a practical research tool for geopolitical analysis. 


\section{The Concept of Intermarium}

It is indicated that the concept of the Intermarium originated during the reign of the Jagiellon dynasty (Cieplucha, 2014, p. 39) or in the nineteenth century, and prince Adam Czartoryski is indicated as its precursor, although the idea was supposed to appear indirectly in the documents of Cyril and Methodius (Koncepcja Międzymorza..., 2015). In Polish tradition, however, it has been accepted that Józef Piłsudski is the spiritual father of the concept (Sykulski, 2014, p. 118). Referring to Piotr Cieplucha, the following definition of the Intermarinum can be adopted: „it is a foreign policy doctrine derived from Polish political thought and practice, which is characterized by the voluntary cooperation of Member States, a defensive character, a common defense of sovereignty and the construction of subjectivity, the implementation of common interests, and a broad nature of cooperation based on the solidarity of Central and Eastern European countries and Poland's initiative in building this coalition" (Cieplucha, 2014,pp. 40-41). Jakub Potulski also pointed to Poland as the leader of such an alliance, but also that the goal of the inter-sea region would be to protect against imperial policy of Germany and Russia, which appear in this case as enemies, and also create conditions for the development of the region. Central European and Baltic countries would become allies (Potulski, 2017, p. 85). On the basis of the mentioned definitions and the elements that make up it, the following features of the Intermarium may be indicated: Polish leadership, voluntary and solidary cooperation of states, defense of sovereignty and subjectivity, work on the development of the region, pursuing common interests, and a common enemy. Generally speaking, it is a voluntary cooperation of Central and Eastern European countries established in order to achieve common goals, such as: development of the region and defense of autonomy under Polish leadership, which is a counterweight to Germany and Russia.

Currently, the Intermarium has returned to Polish discourse, and with it the term three-sea, both used interchangeably. Sometimes it results from confusing their meanings, and sometimes from understanding the second term as a modern continuation of the earlier concept of the Intermarium (Zaniewicz, 2017; Bieńczyk-Missala, 2018). However, the Three Seas concept appears much more frequently in journalistic texts and is then referred to as an element of political ideology rather than a separate geopolitical concept. Such texts indicate that this is a vision of the ruling group in Poland aimed at guaranteeing survival thanks to the support of the US (Problem z koncepcja..., 2017) or taking initiatives aimed at contributing to leveling the level of infrastructure with Europe (Jakóbik, 2017) and is also presented as economic and infrastructural cooperation between EU Member States and those located between the Adriatic, Baltic and Black Sea (Zaniewicz, 2017). The considerations made in the article use the geopolitical concept of the Intermarium, which is considered in the context of the category of militant democracy. This makes it possible to answer the research question regarding the potential for the implementation of the geopolitical concept in militant democracy during or right after the COVID-19 pandemic. 
However, it was considered justified to underline the modern version of the Three Seas concept currently appearing in political discourse, although its journalistic rather than scientific nature raises doubts.

\section{Indicators of Militant Democracy in 2008-2019 in Poland}

Before answering the research question, it is important to outline the level of militant democracy in Poland before the COVID-19 pandemic. The initial turning point of the study is 2008, because there was an economic crisis at the time, the effects of which affected the whole world to a greater or lesser extent, and the final turning point was 2019, i.e. the period before the pandemic. It is very important to remember that there are some restrictions in Poland that were introduced earlier, but are still in force today, e.g. restrictions on the registration of political parties. However, this is not the subject of the study, therefore in this section there are mentioned only these changes and regulations that have appeared in the examined period.

In 2009, a paragraph was added to the Article 99 of the Constitution of the Republic of Poland regarding passive electoral rights in elections to the Sejm and Senate. The provision was expanded to include the premise that ,a person sentenced by a final judgment to imprisonment for an intentional offense prosecuted by public indictment" may not be elected (Ustawa $z$ dnia 7 maja...; Konstytucja RP). In the same year, the Act of 2 April 2009 on Polish Citizenship (Ustawa $z$ dnia 2 kwietnia...) repealed the Act of 15 February 1962 (Ustawa $z$ dnia 15 lutego...). It regulates the issue of acquiring Polish citizenship, the prerequisites for recognition of citizenship and the matter regarding renunciation of citizenship (Ustawa $z$ dnia 2 kwietnia...). In September 2011, the Act on public access to information was reviewed. It was about the right of state authorities to limit or refuse to provide information that could harm ,important interests of the state”. After the Sejm's acceptance of the Senate's amendments, the then president of the Republic of Poland signed the bill (Freedom of the Press 2012). The new regulation on the freedom of assembly appeared on October 9, 2012, then paragraph 2 was added to Article 3 of the Act of July 5, 1990 on the Law of Assemblies (Law of 9...). The amendment referred to the premises that determine the inability to attend an assembly, also regulated the matter of organizing one or more assemblies in the same place and the obligation to inform the organizer about the details of the assembly (Law of 9...). This Act was then replaced by the Act of July 24,2015 on the Law of Assemblies (Ustawa $z$ dnia 24 lipca...). It defined the concept of assembly and partly repeated the provisions of the previous act (Ustawa $z$ dnia 24 lipca...). Another change in this respect took place in 2016 on the amendment of the Act - Assembly Law (Ustawa $z$ dnia 13 grudnia...). The provisions concerned the priority of organizing an assembly in the same place, which also selected other groups in the order of submission of notifications to the competent authority (Ustawa $z$ dnia 13 grudnia...). In June 2014, the Police (with no warrant) entered the editorial office of the weekly "Wprost" (Freedom of the Press 2015...). In December 2015 the 
newly elected parliament adopted a law on "national media" that transferred most of the power - including hiring and releasing journalists - over public media from the regulatory body to the Ministry of the Treasury (Freedom of the Press 2016...). The Helsinki Foundation for Human Rights also noted that local media in Poland are much more vulnerable to legal repression by local authorities than nationwide facilities (Freedom of the Press 2016...), though problems with the freedom of press in Poland were found yet in 2013 in the report of the Polish Open Government Coalition which identified a number of them, including inconsistent enforcement by various government bodies, unjustified processing delays and poorly regulated interpretations of what constitutes public information (Freedom of the Press $2016 \ldots$..). As far as the independence of the judiciary is concerned, problems in this matter have been taking place since 2015 (Szuleka, Wolny, Szwed, 2016; Kowalski, 2020). On the Constitutional Tribunal Act, even the opinion of the Venice Commission was issued (Ustawa $z$ dnia 25 czerwca 2015...; Council of Europe, 2016). It pointed to a number of violations, including a violation of the rule of law when choosing judges, violation of independence, prolongation of the constitutional crisis or the possibility of politicizing the Tribunal (Council of Europe, 2016). On July 12, 2017, an amendment to the Act on the National Council of the Judiciary and certain other acts (Ustawa z dnia 12 lipca 2017a...) and an amendment to the Act on the structure of common courts (Ustawa $z$ dnia 12 lipca $2017 b \ldots$..) were adopted. The first of them assumed, among others, election of members of the National Council of the Judiciary by the Sejm, not judges (Ustawa $z$ dnia 12 lipca $2017 a \ldots)$. The second amendment regarding the structure of common courts assumed, for example, the introduction of a random assignment of cases for judges, invariability of the adjudication panel, or an increase in the competence of the Minister of Justice in the appointment and dismissal of presidents and vice presidents of courts (Ustawa $z$ dnia 12 lipca 2017b...). Further restrictions were introduced by the Act of December 8, 2017 (Ustawa $z$ dnia 8 grudnia 2017...). The amendments increased the dependence of the judiciary on the executive, e.g. if the President of the Republic of Poland defines the first statute of the Supreme Court, he is not obliged to consult the Supreme Court's council (Ustawa $z$ dnia 8 grudnia 2017...). The Act of December 20,2019, pointed to the tightening of disciplinary liability of judges, which may facilitate the imposition of legal solutions violating judicial independence, increasing the powers of court presidents and thus the Minister's of Justice (Bodnar, 2019; Ustawa $z$ dnia 20 grudnia 2019...). The Ombudsman also pointed out to the violation of a number of constitutionally protected principles. In addition, this Act interfered with the freedom of association of judges by the obligation to submit information on membership of associations and foundations and freedom of expression (Bodnar, 2019). Another issue is the preamble, which changed many laws, without the necessary incorporation of amendments to the content of the amended regulations (Bodnar, 2019). On June 10, 2016, the Anti-Terrorism Act appeared, which regulated a number of issues ranging from the definition of terrorist activities and combating terrorism to the definition of bodies that would cooperate in matters of security and crisis management in the implementation of 
anti-terrorist activities (Ustawa $z$ dnia 10 czerwca...). On February 24, 2017, a paragraph was added to the Act on Emergency from June 21,2002 regarding threats related to activity in cyberspace (Ustawa o stanie wyjattkowym...). All the briefly described restrictions that occurred in the considered period and the corresponding indicators were included and illustrated in Table 1.

Table 1. Features of militant democracy in Poland (2008-2019)

\begin{tabular}{lcccccccccccc}
\hline $\begin{array}{l}\text { The type of } \\
\text { measure/ } \\
\text { Years }\end{array}$ & $\mathbf{2 0 0 8}$ & $\mathbf{2 0 0 9}$ & $\mathbf{2 0 1 0}$ & $\mathbf{2 0 1 1}$ & $\mathbf{2 0 1 2}$ & $\mathbf{2 0 1 3}$ & $\mathbf{2 0 1 4}$ & $\mathbf{2 0 1 5}$ & $\mathbf{2 0 1 6}$ & $\mathbf{2 0 1 7}$ & $\mathbf{2 0 1 8}$ & $\mathbf{2 0 1 9}$ \\
\hline M1 & 0 & 0 & 0 & 0 & 1 & 0 & 0 & 1 & 1 & 1 & 1 & 1 \\
\hline M2 & 0 & 0 & 0 & 0 & 1 & 1 & 1 & 1 & 1 & 1 & 1 & 1 \\
\hline M3 & 0 & 0 & 0 & 0 & 0 & 0 & 0 & 0 & 0 & 0 & 0 & 1 \\
\hline M4 & 0 & 0 & 0 & 0 & 0 & 0 & 0 & 0 & 0 & 0 & 0 & 1 \\
\hline M5 & 0 & 0 & 0 & 0 & 0 & 0 & 0 & 0 & 0 & 0 & 0 & 0 \\
\hline M6 & 0 & 1 & 1 & 1 & 1 & 1 & 1 & 1 & 1 & 1 & 1 & 1 \\
\hline M7 & 0 & 0 & 0 & 0 & 0 & 0 & 0 & 0 & 0 & 0 & 0 & 0 \\
\hline M8 & 0 & 0 & 0 & 0 & 0 & 0 & 0 & 0 & 0 & 0 & 0 & 0 \\
\hline M9 & 0 & 0 & 0 & 0 & 0 & 0 & 0 & 0 & 0 & 0 & 0 & 0 \\
\hline M10 & 0 & 0 & 0 & 0 & 0 & 0 & 0 & 0 & 0 & 0 & 0 & 0 \\
\hline M11 & 0 & 1 & 1 & 1 & 1 & 1 & 1 & 1 & 1 & 1 & 1 & 1 \\
\hline M12 & 0 & 0 & 0 & 0 & 0 & 0 & 0 & 0 & 0 & 0 & 0 & 0 \\
\hline M13 & 0 & 0 & 0 & 0 & 0 & 0 & 0 & 0 & 0 & 1 & 1 & 1 \\
\hline M14 & 0 & 0 & 0 & 0 & 0 & 0 & 0 & 0 & 0 & 0 & 0 & 0 \\
\hline M15 & 0 & 0 & 0 & 0 & 0 & 0 & 0 & 1 & 1 & 1 & 1 & 1 \\
\hline
\end{tabular}

Source: own study

0 - a measure was not implemented

1 - a measure was implemented

(M1) the limitations of the freedom of assembly; (M2) the limitations of the freedom of the press, (M3) the limitations of the freedom of speech, (M4) the limitations of the freedom of association, (M5) the limitations of the freedom of religion, (M6) the limitations of passive voting rights; (M7) the limitations of active voting rights; (M8) the limitations of referendum organization; (M9) legislation on counterterrorism and anti-terrorism; (M10) the limitation of registration and functioning of political parties; (M11) the limitation of naturalization; (M12) the limitation of access to public employment; (M13) legislation on anti-extremism; (M14) movement restrictions; (M15) restrictions on the independence of the judiciary. 


\section{Militant Democracy in Poland and the Geopolitical Concept of the Intermarium During the COVID-19 Pandemic}

The first case of COVID-19 in Poland was confirmed on March 4, 2020 (Lasota-Krawczyk \& Makarewicz, 2020). From that moment on, the situation began to develop, and on March 7,2020 , an act was announced on specific solutions related to the prevention and control of COVID-19, other infectious diseases and emergencies caused by them (Ustawa $z$ dnia 7 marca...). Since then border controls have been announced and numerous recommendations issued, e.g. on suspension of mass events, preventive measures. March 11 was notified, among others, on the closure of educational, artistic, etc. institutions based on the relevant regulation (aba, 2020).

Just two days later, on March 13, 2020, an epidemic emergency was introduced in Poland by a regulation of the Minister of Health (Rozporzadzenie Ministra Zdrowia 13.03...). In relation to it, the following restrictions were introduced: restrictions on movement and the obligation to quarantine after returning from abroad; restrictions or prohibitions related to the marketing and use of items listed in the Regulation, such as, for example, wearing safety goggles, surgical masks, latex gloves, etc.; restrictions on the functioning of specific institutions or workplaces, including those related to the operation of gastronomy, culture or the listed commercial facilities; a ban on organizing shows and gatherings of over 50 people (Rozporzadzenie Ministra Zdrowia 13.03...).

Further restrictions were introduced on March 24, 2020: movement was further restricted except for the way to and from work, volunteering related to COVID-19 and dealing with necessary matters for life; a ban on assemblies and the organization of events, with the exception of events involving persons in regular living and family members; limiting the number of people who can travel by public transport; the buildings of religious worship may contain a maximum of 50 people, while in the case of funerals, 5 participants, except those carrying religious worship or people employed by the funeral home (Rozporzadzenie Ministra Zdrowia 24.03...).

The most important restrictions announced on March 31 include: the obligation to keep a minimum distance of 2 meters between pedestrians, except for parents with children under 13 and dependent persons; kids cannot leave the home unattended, access to city bikes, green areas, beaches, parks, promenades, etc.; maximum limits have been imposed on persons who may be present in stores at the same time; a ban on operating on large-area construction stores in weekends was introduced; and hairdressers, cosmetics, tattoo and piercings salons were closed; between 10-12 hours only persons over 65 years of age may use the stores (Rozporządzenie Rady Ministrów 31.03).

The restriction, which was introduced on April 9, 2020, before Easter celebrated by Catholics is: an order to cover the nose and mouth in public places and the extension of earlier ones. In addition, it was recommended to stay at home during the holidays and to postpone the unspecified date of final exams and eighth-graders Rząd przedtuża...). 
Most restrictions were predicted to be in force until the end of April, dependently on the development of the epidemiological situation.

The use of sooner extracted indicators to analyze the situation in Poland in terms of the characteristics of militant democracy show that the restrictions in both March and April concerned only assemblies, religious freedom and movement (see Table 2). However, as mentioned, much more restrictions appeared, although they were not included in the research tool created. This does not mean that it was poorly constructed or inadequately selected. This is primarily due to the theoretical premise, i.e. a kind of conceptualization and practicality, i.e. a situation that so far has not occurred for many years, both in the period under study and before, when the category of militant democracy was firstly used. There are numerous opinions and forecasts indicating that a pandemic will cause a bigger crisis than the one that appeared in 2008 (Tooze, 2020), which is the initial turning point in the study. Therefore, consideration should be given to expanding the catalog of features specific to militant democracy or to better adapt this category to contemporary political conditions.

Such attempts are currently being made as a part of the reconstruction of the neo-militant democracy category. This category was considered by researchers, e.g. in relation to Hungary (Rak, 2020). This case was mentioned because Katarina Barley, who served as deputy head of the European Parliament, said that Poland and Hungary should be brought before an EU tribunal. As a reason, she indicated violations of human rights and democracy during the COVID-19 pandemic, taking advantage of the situation to introduce authoritarian solutions (Stańczyk, 2020).At this point, it should be emphasized that in the scientific discourse there is a distinction between the solutions specific to authoritarianism and the mechanisms of militant democracy. However, it is missing in the source or journalistic language. During the pandemic, informal restrictions are also introduced, e.g. local restrictions on press freedom (Kozielski, 2020), police controls for those moving during the holiday season (agada, 2020) or running tickets (Maciuszczak \& Szydłowski, 2020). Doubts are also raised by the introduction of amendments to the Electoral Code regarding correspondence voting for all citizens (initially only for the elderly) in the May presidential election (Chmielewska, 2020).

The extension of the created catalog of indicators and restrictions is, however, a broad topic for further scientific works. The two months of the pandemic analyzed can be described as the first stage of the fight against COVID-19 in Poland. The purpose of the article is, however, to check whether it will be possible to implement the concept of the Intermarium concept during the pandemic and shortly after its end, therefore, it is necessary to briefly mention the restrictions introduced in Russia, which are different than in the case of Poland. The most important restrictions include: closing the borders with China and Mongolia; limitation of air and rail connections; entry ban for Chinese citizens and ultimately for all foreigners; assembly bans depending on the circumference of over 50 or 100 people; the establishment of an Information Center to control and block unreliable and potentially dangerous information placed on social media (Koronawirus w Rosji...). 
Intermarium, as established on the basis of literature review, is a voluntary cooperation of Central and Eastern European countries established in order to achieve common goals, such as: development of the region and defense of autonomy, under Poland's leadership, constituting a counterweight to Germany and Russia.

In view of the presented analyzes, two scenarios seem likely. The first assumes that after the havoc that the pandemic has done, the states will close even more than during its duration and will try to tackle the negative epidemiological effects on their own. At this point, the question arises whether, after the pandemic has expired, the concept of an Intermarium will be right at all and will return to political discourse.

The second scenario assumes treating the concept of the Intermarium region as a salvation for countries that will face the global crisis. Then, the creation of an Intermarium area would be implemented primarily as mutual assistance and cooperation. However, in the

Table 2. Features of militant democracy in Poland during the coronavirus pandemic (March-April 2020)

\begin{tabular}{ccc}
\hline The type of measure/Months & March & April \\
\hline M1 & $\mathbf{1}$ & $\mathbf{1}$ \\
\hline M2 & 1 & 1 \\
\hline M3 & 0 & 0 \\
\hline M4 & 0 & 0 \\
\hline M5 & $\mathbf{1}$ & $\mathbf{1}$ \\
\hline M6 & 1 & 1 \\
\hline M7 & 0 & 0 \\
\hline M8 & 0 & 0 \\
\hline M9 & 0 & 0 \\
\hline M10 & 0 & 0 \\
\hline M11 & 1 & 1 \\
\hline M12 & 0 & 0 \\
\hline M13 & 1 & 1 \\
\hline M14 & $\mathbf{1}$ & $\mathbf{1}$ \\
\hline M15 & 1 & 1 \\
\hline
\end{tabular}

Source: own study

0 - a measure was not implemented

1 - a measure was implemented

1 - a measure was implemented during the pandemic (bold font)

(M1) the limitations of the freedom of assembly; (M2) the limitations of the freedom of the press, (M3) the limitations of the freedom of speech, (M4) the limitations of the freedom of association, (M5) the limitations of the freedom of religion, (M6) the limitations of passive voting rights; (M7) the limitations of active voting rights; (M8) the limitations of referendum organization; (M9) legislation on counterterrorism and anti-terrorism; (M10) the limitation of registration and functioning of political parties; (M11) the limitation of naturalization; (M12) the limitation of access to public employment; (M13) legislation on anti-extremism; (M14) movement restrictions; (M15) restrictions on the independence of the judiciary. 
face of the growing number of cases in Poland and Russia, the potential for counterbalance is in doubt. It also seems that the Intermarium goal of defending autonomy would not be a priority either, because a pandemic would involve states sufficiently in rebuilding their economies.

At the very beginning one should answer the research question (what is the potential for implementing the concept of Intermarium in the context of the category of militant democracy during or right after the COVID-19 pandemic?): very low, if any. In case that the question would omit the element of a pandemic situation completely, the chances of this would increase significantly, as militant democracy mechanisms, which existence indicates the closing and isolation of states, would probably not be used, while for implementing this particular concept they must maintain a certain specific level of openness, whether to display features of a vitalistic attitude. Of course, the implementation of the concept of the Intermarium could be inhibited by other factors, e.g. the image of Poland on the international stage or assessment of its potential to become a leader of countries cooperating within the Intermarium, but they would not lead to the elimination of this concept to the extent when it implements militant democracy mechanisms. In the face of this statement, it seems that after the pandemic expires, the political situation of many countries may be so difficult that of the two scenarios indicated, the first seems more likely. Each state will struggle with the crisis on its own, perhaps with a minimal degree of cooperation, but certainly not in any way sanctioned. In the face of a pandemic, the three-sea concept seems unrealistic as the US is starting to outdo the number of victims, even in Italy and Spain.

\section{Results and Conclusions}

In the face of the analysis that was carried out, it seems that in a pandemic situation we are observing the end of the paradigm of liberal democracy in this case (due to the increasingly important features of armored democracy in Central and Eastern European countries), but also the Intermarium paradigm. Currently, Poland is more inclined to the concept of the three seas than the Intermarium, and the chosen direction of obtaining support from the US is to arouse the reluctance of countries such as Hungary, the Czech Republic and Slovakia (Pieczyński, 2018), i.e. potential cooperating countries, if they refer to the older concept. In addition, on the one hand, Russia's fear of implementing the three-sea concept, and on the other hand, paradoxically, its belief in the unreality of Poland's plans in this regard, increases its interest in the discussed idea, and at the same time less attention is paid to the concept of the Intermarium (Rosja boi się..., 2017; Alternatywa dla gazu..., 2018). One may wonder how in the face of the pandemic some views, statements and concepts may be redefined, but this does not change the fact that the traditional concept of the Intermarium is eroded due to natural causes. The coronavirus pandemic also proves this by outdating the assumption of the concept of the Intermarium environment, according to which the enemies are Germany 
and Russia, while the new enemy is potentially ubiquitous, invisible, and therefore difficult to pinpoint and capture. In addition, the goal of increasing the autonomy of states that would form part of the Intermarium zone loses its strategic importance or at least priority in this situation. In addition, the very existence of structures such as the European Union or the Visegrad Group reduces the chances of implementing the concept of the Intermarium as another community structure which interests may turn out to be incompatible or even contradictory and leading to conflicts within the continent.

In mid-April 2020 it is too early to be able to debate about the full geopolitical effects of the coronavirus pandemic, as its scale is still a very dynamic variable. The concept of the Intermarium proves to be a valuable research tool for assessing the current situation in Eastern and Central Europe, enabling the creation of previously identified specific postpandemic scenarios. One of them relates to the independent struggle of countries with the crisis and a small degree of cooperation between them, the other to the implementation of the concept of the Intermarium, which, however, would have to be significantly reformulated or replaced by the concept of the Three Seas. The theoretical weakness of this perspective is its geographical fragmentation, which allows to capture, for example, some US interests, but eliminates from the research field another superpower that is actively participating in the race for the extent of political influence in the world, i.e. China. In turn, the practical verification of the feasibility of this concept is its test in the context of the militant democracy category, the result of which minimizes or even eliminates the scenario of expanding the scope of international cooperation. After all, this perspective requires additional verification in the form of time, because currently too many variables appear that can change the course of the situation. It is also a fact that it is in Russia's interest not to allow neighboring countries to form in another alliance, all the more a newly defined concept of the Intermarium, which also speaks for its natural end.

\section{References:}

aba. (2020). Weszło $w$ życie rozporządzenie w sprawie zamknięcia szkót i przedszkoli. Retrieved from: https:// samorzad.pap.pl/kategoria/aktualnosci/weszlo-w-zycie-rozporzadzenie-w-sprawie-zamkniecia-szkoli-przedszkoli [Accessed 13 April 2020].

agada. (2020). Czy można jechać do rodziny na Wielkanoc? Policja zapowiada kontrole. Retrieved from: https://www.eska.pl/olsztyn/czy-mozna-jechac-do-rodziny-na-swieta-w-wielkanoc-2020-policja-zapowiada-kontrole-aa-L1zR-obVj-Br7c.html [Accessed 14 April 2020].

Alternatywa dla gazu od Putina? Międzymorze i energia z USA! Prof. Chodakiewicz: Niemcy nie mieliby wymówki bycia w tóżku z Rosjanami. (2018). Retrieved from: https://wpolityce.pl/polityka/403652chodakiewicz-koniec-wymowki-niemiec-bycia-w-lozku-z-rosja [Accessed 14 April 2020].

Bieńczyk-Missala, A. (2018). “Od międzymorza do Trójmorza - meandry polityki zagranicznej Polski w Europie Środkowej”. Stosunki międzynarodowe, 1(54).

Bodnar, A. (2019). Retrieved from: https://www.rpo.gov.pl/sites/default/files/Opinia\%20dla\%20 Marszałka\%20Senatu\%20ws.\%20ustaw\%20sądowych\%20z\%2020\%20grudnia\%202019\%20r.\%20

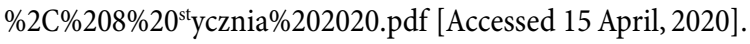


Capoccia, G. (2005). Defending Democracy Reactions to Extremism in Interwar Europe. Baltimore, London. Chmielewska, M. (2020). Wybory w czasach koronawirusa. „Diabeł tkwi w szczegółach” [3 PYTANIA DO] Retrieved from: http://tylkotorun.pl/wybory-w-czasach-koronawirusa-diabel-tkwi-w-szczegolach-3-pytania-do/?fbclid=IwAR1XMu27-kBtJXxrSOKbxjLHNJDHcFefiB1Th7gK9848hpSGMwz5DxFMSgQ [Accessed 14 April 2020].

Cieplucha, P. (2014). “Prometeizm i koncepcja międzymorza w praktyce polityczno-prawnej oraz dyplomacji II RP”. Studia prawno-ekonomiczne, 93(XCIII).

Freedom of the Press 2012. Poland. Retrieved from: https://www.refworld.org/docid/508fa387c.html [Accessed 13 April 2020].

Council of Europe Poland. (2016). Opinion on the Act on the Constitutional Tribunal, adopted by the Venice Commission at its $108^{\text {th }}$ Plenary Session, (Venice, 14-15 October 2016) Retrieved from: https://www. venice.coe.int/webforms/documents/?pdf=CDL-AD(2016)026-e [Accessed 15 April 2020].

Freedom of the Press 2015. Poland. Retrieved from: https://www.refworld.org/docid/55cb45d815.html [Accessed 13 April 2020].

Freedom of the Press 2016. Poland. Retrieved from: https://www.refworld.org/docid/57f361d213.html [Accessed 17 March 2020].

Ijabs, I. (2016). "After the Referendum: Militant Democracy and Nation-Building in Latvia”. East European Politics and Societies and Cultures, 2(30), 288-314.

Jakóbik, W. (2017). Jakóbik: Trójmorze to nie międzymorze a Trump być może pomoże. Retrieved from: https://biznesalert.pl/jakobik-trojmorze-miedzymorze-a-trump-byc-moze-pomoze/ [Accessed 11 April 2020].

Kirshner, A. (2014). A Theory of Militant Democracy: The Ethics of Combatting Political Extremism. New Haven and London: Yale University Press.

Konstytucja Rzeczypospolitej Polskiej z dnia 2 kwietnia 1997 roku. Retrieved from: http://prawo.sejm.gov. pl/isap.nsf/download.xsp/WDU19970780483/U/D19970483Lj.pdf [Accessed 13 April 2020].

Koronawirus w Rosji. Niewiarygodne statystyki, spóźnione działania. (2020). Retrieved from: https:// warsawinstitute.org/pl/koronawirus-w-rosji-niewiarygodne-statystyki-spoznione-dzialania/ [Accessed 14 April 2020].

Kowalski, N. (2020). Wojna o sądy trwa: Chaos, bałagan, masowo uchylane wyroki i przeciagane procesy? Cierpia na tym zwykli obywatele. Retrieved from: https://plus.gloswielkopolski.pl/wojna-o-sady-trwachaos-balagan-masowo-uchylane-wyroki-i-przeciagane-procesy-cierpia-na-tym-zwykli-obywatele/ ar/c1-14751244 [Accessed 15 April 2020].

Kozielski, M. (2020). Toruńscy dziennikarze zarzucaja prezydentowi miasta cenzurowanie pytań. Retrieved from: https://www.press.pl/tresc/61119,torunscy-dziennikarze-zarzucaja-prezydentowi-miastacenzurowanie-pytan [Accessed 14 April 2020].

Lasota-Krawczyk, J., \& Makarewicz, N. (2020). Koronawirus w Polsce. Pierwszy przypadek potwierdzony. Retrieved from: https://www.rmf24.pl/raporty/raport-koronawirus-z-chin/najnowsze-fakty/newskoronawirus-w-polsce-pierwszy-przypadek-potwierdzony,nId,4346987 [Accessed 13 April 2020].

Loewenstein, K. (1937a). "Militant Democracy and Fundamental Rights I". The American Political Science Review, 3(31), 417-432.

Loewenstein, K. (1937b). “Militant Democracy and Fundamental Rights II”. The American Political Science Review, 4(31), 638-658.

Maciuszczak, T., \& Szydłowski, J. (2020). Surowe mandaty za bieganie. Wokół legalności nakładanych kar pojawiaja się wattpliwości prawne. Retrieved from: https://www.dziennikwschodni.pl/lublin/ 
surowe-mandaty-za-bieganie-wokol-legalnosci-nakladanych-kar-pojawiaja-sie-watpliwosciprawne,n,1000264081.html [Accessed 14 April 2020].

Macklem, P. (2006). "Militant Democracy, Legal Pluralism, and the Paradox of Self-determination”. International Journal of Constitutional Law, 3(4), 488-516.

Mareš, M. (2012). "Czech Militant Democracy in Action: Dissolution of the Workers' Party and the Wider Context of This Act". East European Politics and Societies, 33(26), 33-55.

Marszałek-Kawa, J. (2019). The Institutional Position and Functions of the Sejm of the Republic of Poland after the Accession to the European Union. Odessa: Helvetica Publishing House.

Marszałek-Kawa, J., Plecka, D. \& Hołub, A. (Eds.). (2018). Social Security. Selected Aspects, Toruń: Adam Marszałek Publishing House.

Marszałek-Kawa, J., Plecka, D. (2019). The State Security Policy in National Security Strategies of the Republic of Poland in the Years 2002-2014. Toruń: Adam Marszałek Publishing House.

Marszałek-Kawa, J., Siemiątkowski, P. (Eds.). (2020). Expose prezesów Rady Ministrów 1989-2019. Toruń: Adam Marszałek Publishing House.

Molier, G., \& Rijpkema, B. (2018). “Germany’s New Militant Democracy Regime: National Democratic Party II and the German Federal Constitutional Courts's 'Potentiality' Criterion for Party Bans: Bundesverfassungsgericht, Hudgment of 17 January 2017, 2 BvB 1/13, National Democratic Party II”. European Constitutional Law Review, 2(14), 394-409.

Müller, J.-W. (2012). “Militant Democracy”. In M. Rosenfeld \& A. Sajó (Eds.), The Oxford Handbook of Comparative Constitutional Law (1119). New York: Oxford University Press. DOI: https://doi.org/ oxfordhb/9780199578610.013.0062.

Potulski, J. (2017). “Podstawowe polskie kody geopolityczne - Polska jako Międzymorze”. Gdańskie Studia Międzynarodowe, 15(1-2), 80-96.

Pieczyński, M. (2018). Rosjanie o międzymorzu: nierealne marzenie Warszawy. Retrieved from: https:// dorzeczy.pl/tylko-na-dorzeczy/67055/Rosjanie-o-Miedzymorzu-Nierealne-marzenie-Warszawy.html [Accessed 14 April 2020].

Problem z koncepcja międzymorza jest analogiczny jak z koncepcją neutralności Polski. (2017). Retrieved from: https://obserwatorpolityczny.pl/problem-koncepcja-miedzymorza-analogiczny-koncepcjaneutralnosci-polski/ [Accessed 12 April 2020].

Rak, J. (2020). “Conceptualizing the Theoretical Category of Neo-militant Democracy: The Case of Hungary”. Polish Political Science Yearbook, 2(49).

Redakcja. (2015). Koncepcja Międzymorza: historia i perspektywa rozwoju. Retrieved from: https://jagiellonia.org/koncepcja-miedzymorza-historia-perspektywa-rozwoju/ [Accessed 12 April 2020].

Rosja boi się „mocarstwowych zapędów Polski”? Rosyjski ekspert: Warszawa chce odbudować Międzymorze i swoje wpływy. (2020). Retrieved from: https://forsal.pl/artykuly/1055418,rosja-boi-sie-mocarstwowych-zapedow-polski-rosyjski-ekspert-warszawa-chce-odbudowac-miedzymorze-i-swoje-wplywy. html [Accessed 14 April 2020].

Rozporządzenie Ministra Zdrowia z dnia 13 marca 2020 r. w sprawie ogłoszenia na obszarze Rzeczypospolitej Polskiej stanu zagrożenia epidemicznego. (2020). Retrieved from: http://prawo.sejm.gov.pl/ isap.nsf/download.xsp/WDU20200000433/O/D20200433.pdf [Accessed 13 April 2020].

Rozporządzenie Ministra Zdrowia z dnia 24 marca 2020 r. zmieniające rozporządzenie w sprawie ogłoszenia na obszarze Rzeczypospolitej Polskiej stanu epidemii. (2020). Retrieved from: http://prawo.sejm.gov. pl/isap.nsf/download.xsp/WDU20200000522/O/D20200522.pdf [Accessed 13 April 2020]. 
Rozporządzenie Rady Ministrów z dnia 31 marca 2020 r. w sprawie ustanowienia określonych ograniczeń, nakazów i zakazów w związku z wystąpieniem stanu epidemii. (2020). Retrieved from: http://isip. sejm.gov.pl/isap.nsf/download.xsp/WDU20200000566/O/D20200566.pdf [Accessed 13 April 2020].

Rząd przedłuża obostrzenia $w$ walce $z$ koronawirusem. (2020). Retrieved from: https://www.gov.pl/web/ mswia/rzad-przedluza-obostrzenia-w-walce-z-koronawirusem [Accessed 13 April 2020].

Sajó, A. (2005). “From Militant Democracy to the Preventive State”. Cardozo Law, 5(27), 2255-2294.

Stańczyk, Z. (2020). Wiceszefowa Parlamentu Europejskiego żąda postawienia Polski $i$ Węgier przed unijnym trybunałem za wykorzystywanie pandemii koronawirusa do łamania demokracji. Retrieved from: https://shareinfo.pl/wiceszefowa-parlamentu-europejskiego-zada-postawienia-polski-i-wegierprzed-unijnym-trybunalem-za-wykorzystywanie-pandemii-koronawirusa-do-lamania-demokracji/ [Accessed 14 April 2020].

Szuleka, M., Wolny, M., Szwed, M. (2016). Kryzys konstytucyjny w Polsce 2015-2016 Retrieved from: http:// www.hfhr.pl/wp-content/uploads/2016/09/HFPC-Kryzys-konstytucyjny-w-Polsce-2015-2016.pdf [Accessed 15 April 2020].

Tooze, A., (2020). Is the Coronavirus crash worse than the 2008 Financial Crisis? Retrieved from: https:// foreignpolicy.com/2020/03/18/coronavirus-economic-crash-2008-financial-crisis-worse/[Accessed 14 April 2020].

Ustawa z dnia 7 maja 2009 r. o zmianie Konstytucji Rzeczypospolitej Polskiej. (2009). Retrieved from: http://prawo.sejm.gov.pl/isap.nsf/download.xsp/WDU20091140946/O/D20090946.pdf [Accessed 13 April 2020].

Ustawa z dnia 15 lutego 1962 r. o obywatelstwie polskim. (1962). Retrieved from: http://obywatelstwo.eu/ obywatelstwo3.html\#1 [Accessed 13 April 2020].

Ustawa z dnia 2 kwietnia 2009 r. o obywatelstwie polskim. (2009). Retrieved from: http://prawo.sejm.gov. pl/isap.nsf/download.xsp/WDU20120000161/U/D20120161Lj.pdf [Accessed 13 April 2020].

Law of 9 October 2012 on amending the law - Law on Assemblies. (2012). Retrieved from: https://www. legislationline.org/download/id/4827/file/Law_amending_\%20Law\%20on\%20assemblies1990_2012_ en.pdf [Accessed 13 April 2020].

Ustawa z dnia 24 lipca 2015 r., Prawo o zgromadzeniach. (2015). Retrieved from: http://prawo.sejm.gov. pl/isap.nsf/download.xsp/WDU20150001485/U/D20151485Lj.pdf [Accessed 13 April 2020].

Ustawa z dnia 13 grudnia 2016 r. o zmianie ustawy - Prawo o zgromadzeniach (2016). Retrieved from: http://prawo.sejm.gov.pl/isap.nsf/download.xsp/WDU20170000579/O/D20170579.pdf [Accessed 13 April 2020].

Ustawa z dnia 10 czerwca 2016 r. o działaniach antyterrorystycznych. (2016). Retrieved from: http://prawo. sejm.gov.pl/isap.nsf/download.xsp/WDU20160000904/U/D20160904Lj.pdf [Accessed 25 March 2020].

Ustawa z dnia 21 czerwca 2002 r. o stanie wyjątkowym. (2002). Retrieved from: http://prawo.sejm.gov.pl/ isap.nsf/download.xsp/WDU20021130985/U/D20020985Lj.pdf [Accessed 13 April 2020].

Ustawa z dnia 2 marca 2020 r. o szczególnych rozwiązaniach związanych z zapobieganiem, przeciwdziałaniem i zwalczaniem COVID-19, innych chorób zakaźnych oraz wywoływanych nimi sytuacji kryzysowych (2020). Retrieved from: http://dziennikustaw.gov.pl/D2020000037401.pdf [Accessed 13 April 2020].

Ustawa z dnia 25 czerwca 2020 r. o Trybunale Konstytucyjnym (2020). Retrieved from: http://prawo.sejm. gov.pl/isap.nsf/download.xsp/WDU20150001064/U/D20151064Lj.pdf [Accessed 15 April 2020].

Ustawa z dnia 12 lipca 2017a r. o zmianie ustawy - Prawo o ustroju sądów powszechnych oraz niektórych innych ustaw (2017). Retrieved from: http://prawo.sejm.gov.pl/isap.nsf/download.xsp/ WDU20170001452/O/D20171452.pdf [Accessed 15 April 2020]. 
Ustawa z dnia 12 lipca 2017a r. o zmianie ustawy - o Krajowej Radzie Sądownictwa oraz niektórych innych ustaw (2017). Retrieved from: http://orka.sejm.gov.pl/proc8.nsf/ustawy/1423_u.htm [Accessed 15 April 2020].

Ustawa z dnia 8 grudnia 2017 r. o Sądzie Najwyższym (2017). Retrieved from: http://prawo.sejm.gov.pl/ isap.nsf/download.xsp/WDU20180000005/T/D20180005L.pdf [Accessed 15 April 2020].

Ustawa z dnia 20 grudnia 2019 o zmianie ustawy - Prawo o ustroju sądów powszechnych, ustawy o Sądzie Najwyższym oraz niektórych innych ustaw (2019). Retrieved from: http://prawo.sejm.gov.pl/isap.nsf/ download. xsp/WDU20200000190/U/D20200190Lj.pdf [Accessed 15 April 2020].

Zaniewicz, Maciej, 2017. Międzymorze czy trójmorze? Słownik koncepcji polskiej polityki wschodniej. Retrieved from: https://www.eastbook.eu/2017/10/11/miedzymorze-czy-trojmorze-slownik-koncepcjipolskiej-polityki-wschodniej/ [Accessed 12 April 2020]. 